DOI: 10.17707/AgricultForest.65.2.06

\author{
Vera RAJIČIĆ, Jelena MILIVOJEVIĆ, \\ Vera POPOVIĆ, Snežana BRANKOVIĆ, \\ Nenad ĐURIĆ, Vesna PERIŠIĆ, Dragan TERZIĆ 1

\section{WINTER WHEAT YIELD AND QUALITY DEPENDING ON THE LEVEL OF NITROGEN, PHOSPHORUS AND POTASSIUM FERTILIZATION}

\begin{abstract}
SUMMARY
Tests were carried out on stationary field trial, soil type vertisol in the process of degradation. The land on which the view is derived is characterized by low $\mathrm{pH} \quad(\mathrm{pH}<5.0)$. The Dose of nitrogen was $120 \mathrm{~kg} \mathrm{~N} / \mathrm{ha}$, which was administered in combination with phosphorous and potassium fertilizer. The tests showed a significant grain yield. Nitrogen had a most significant impact on the yield of wheat. The average grain yield of all treatments in the 2008/09 growing season was significantly greater than in the following years, mostly as the result of highly favourable weather conditions at major stages of plant development. The average highest yield was achieved in the variant N120P100K60 (5.528 t/ha), although the high yield of more than $5 \mathrm{t} / \mathrm{ha}$ was obtained and the triple treatments NPK where nitrogen is applied in the maximum amount of $120 \mathrm{~kg} / \mathrm{ha}$, $60 \mathrm{~kg} / \mathrm{ha} \mathrm{P}_{2} \mathrm{O}_{5}$ and $60 \mathrm{~kg} / \mathrm{ha} \mathrm{K}_{2} \mathrm{O}$ as well as variants $\mathrm{NP}$ in a quantity of 100 $\mathrm{kg} / \mathrm{ha} \mathrm{P}_{2} \mathrm{O}_{5}$ and $60 \mathrm{~kg} / \mathrm{ha} \mathrm{K}_{2} \mathrm{O}$. Also, the 1000 -grain weight was highest in balanced fertilization with all nutrients NPK (40 g), in a quantity of $120 \mathrm{~kg}$ N/ha, $100 \mathrm{~kg} / \mathrm{ha} \mathrm{P}_{2} \mathrm{O}_{5}$ and $60 \mathrm{~kg} / \mathrm{ha} \mathrm{K}_{2} \mathrm{O}$. Averaged across years, significantly higher values for test weight were found in the control $(76.91 \mathrm{~kg} / \mathrm{hl})$. Variance analysis showed statistically significant differences for grain yield and test weight between the vegetation seasons. Significant differences for 1000 grain weight between the variants of fertilization.
\end{abstract}

Keywords: fertilization, mineral nutrition, yield, wheat

\title{
INTRODUCTION
}

Wheat productivity and grain quality in Central Serbia are governed by a range of factors, notably climate, soil, genetics and crop nutrition. Soil acidity in wheat fields in Central Serbia has become a severe problem that leads to a significant decline in grain yield and quality of wheat (Đekić et al., 2017a, 2019;

\footnotetext{
${ }^{1}$ Vera Rajičić, Jelena Milivojević, Vesna Perišić, Small Grains Research Centre, Save Kovačevića 31, Kragujevac, SERBIA; Vera Popović, (corresponding author: bravera@eunet.rs), Institute of Field and Vegetable Crops, Maksima Gorkog 30, Novi Sad, SERBIA; Nenad Đurić, Megatrend University, Faculty of Biofarming, Bačka Topola, SERBIA; Snezana Brankovic, University of Kragujevac, Faculty of Science, Institute of Biology and Ecology, Radoje Domanović 12, Kragujevac, SERBIA; Dragan Terzic, Institute for forage crops, Globoder bb, Kruševac, SERBIA Notes: The authors declare that they have no conflicts of interest. Authorship Form signed online.
} 
Jelic et al., 2015). The yield per unit area is the result of the action of factors of variety in interaction with environmental factors. The yield is largely dependent on the genetic potential and considerably vary primarily as a result of agroecological conditions during the growing season (Dodig et al., 2008; Hristov et al., 2011; Đekić et al., 2017b; Jelić et al., 2014; Djuric et al., 2018; Jordanovska et al., 2018; Popović et al., 2016, 2018; Terzić et al., 2018b).

Mineral fertilizers play a vital role towards improving crop yields but one of the main constraints in achieving proven crop potential is imbalanced use of nutrients, particularly low use of $\mathrm{P}$ as compared to $\mathrm{N}$. The optimum rate of $\mathrm{P}$ application is important in improving yields of most crops (Jelic et al., 2013). Plant nitrogen nutrition has a great impact on the technological quality of wheat cultivars. Nitrogen, in interaction with other elements of mineral nutrition, plays a significant role in the grain yield and quality (Jelic et al., 2014; Đekić et al., 2014, 2017a; Popović et al., 2017; Terzic et al., 2018a). For high yield and grain quality, it is necessary to adopt nitrogen by plants during the whole vegetation period (Jelić et al., 2015). Understanding the fertilization, liming and rainfall effects have been a continuous endeavor toward improving farming technology and management strategy to reduce the negative impacts of these factors and to increase crop yield (Đekić et al., 2019; Jelić et al., 2016; Popović et al., 2017; Terzic et al., 2018a,b).

The objective of this study was to evaluate the effect of different fertilization systems on the grain yield and quality of wheat grown on a vertisol soil. The study was also aimed at optimizing fertilization for maximum profitability in the future wheat production of Central Serbia.

\section{Experimental design \\ MATERIAL AND METHODS}

The study was carried out in a stationary field trial involving fertilization over a three years period from 2008/09, 2009/10 to 2010/11. Trials were first set up in the experimental fields of the Small Grains Research Centre in Kragujevac in 1970. Plot size was $50 \mathrm{~m}^{2}$. The trial was set up in a randomized block design with five replications. Fertilization was regular and followed a long-time scheme.

The rates of nitrogen application were $120 \mathrm{~kg} / \mathrm{ha} \mathrm{N}$, and they were applied either individually or in combination with two phosphorus rates and a potassium fertilizer. A non-fertilized variant served as a control. The winter wheat cultivar used in the experiment was "Vizija", the dominant cultivar in the production region of Serbia. Eight variants of mineral nutrition N (120 kg/ha N), $\mathrm{P}_{1}\left(60 \mathrm{~kg} / \mathrm{ha} \mathrm{P}_{2} \mathrm{O}_{5}\right)$, $\mathrm{P}_{2}\left(100 \mathrm{~kg} / \mathrm{ha} \mathrm{P}_{2} \mathrm{O}_{5}\right), \mathrm{NP}_{1}\left(120 \mathrm{~kg} / \mathrm{ha} \mathrm{N}\right.$ and $\left.60 \mathrm{~kg} / \mathrm{ha} \mathrm{P}_{2} \mathrm{O}_{5}\right), \mathrm{NP}_{2}(120 \mathrm{~kg} / \mathrm{ha} \mathrm{N}$ and $\left.100 \mathrm{~kg} / \mathrm{ha} \mathrm{P}_{2} \mathrm{O}_{5}\right), \mathrm{NP}_{1} \mathrm{~K}\left(120 \mathrm{~kg} / \mathrm{ha} \mathrm{N}, 60 \mathrm{~kg} / \mathrm{ha} \mathrm{P}_{2} \mathrm{O}_{5}\right.$ and $\left.60 \mathrm{~kg} / \mathrm{ha} \mathrm{K}_{2} \mathrm{O}\right)$, $\mathrm{NP}_{2} \mathrm{~K}\left(120 \mathrm{~kg} / \mathrm{ha} \mathrm{N}, 100 \mathrm{~kg} / \mathrm{ha} \mathrm{P}_{2} \mathrm{O}_{5}\right.$ and $\left.60 \mathrm{~kg} / \mathrm{ha} \mathrm{K}_{2} \mathrm{O}\right)$ and untreated control were tested in the experiment. Total amounts of phosphorus and potassium fertilizers and half the nitrogen rate are regularly applied during pre-sowing cultivation of soil.

The crop was harvested at full maturity. Grain yield ( $\mathrm{t} / \mathrm{ha}$ ) was harvested and reported at $14 \%$ moisture. Three parameters, namely grain yield, 1000-grain 
weight (g) and test weight $(\mathrm{kg} / \mathrm{hl})$ were analyzed. Thousand grain weight was determined using an automatic seed counter. Test weight is the weight of a measured volume of grain expressed in kilograms per hectoliter.

\section{Soil analysis}

The trial was set up on a vertisol soil in a process of degradation, with heavy texture and very coarse and unstable structure. The humus content in the surface layer of soil was low (2.22\%). The reduced humus content in field vertisols profiles suggests the necessity of involving humification when planning fertilization systems and soil ameliorative operations to be used to maintain and improve the soil adsorption complex. Soil $\mathrm{pH}$ indicates high acidity $\left(\mathrm{pH}\right.$ in $\mathrm{H}_{2} \mathrm{O}$ 5.19 ; $\mathrm{pH}$ in $\mathrm{KCl} 4.27)$, nitrogen content in soil is medium $(0.11-0.15 \%)$, while the content of available phosphorus ranges from very low (1.7-2.9 mg $100 \mathrm{~g}^{-1}$ soil) in the $\mathrm{N}$ and $\mathrm{NK}$ trial variants to very high (26.9 $\mathrm{mg} \mathrm{P}_{2} \mathrm{O}_{5} 100 \mathrm{~g}^{-1}$ soil) in the NPK variants of fertilization. Available potassium contents are high, ranging from 19.5 to $21.0 \mathrm{mg} \mathrm{K}_{2} \mathrm{O} 100 \mathrm{~g}^{-1}$ soil.

\section{Statistical Analysis}

On the basis of achieved research results the usual variational statistical indicators were calculated: average values and standard deviation. Experimental data were analysed by descriptive and analytical statistics using the statistics module Analyst Program SAS/STAT (SAS Institute, 2000) for Windows. All evaluations of significance were made on the basis of the ANOVA test at $5 \%$ and $1 \%$ significance levels. Relative dependence was defined through correlation analysis (Pearson's correlation coefficient), and the coefficients that were obtained were tested at the $5 \%$ and $1 \%$ levels of significance.

\section{Meteorological conditions}

\section{RESULTS AND DISCUSSION}

This study was conducted over a three-year period in the Sumadija region, Central Serbia, on a Vertisol soil, at Kragujevac location, (44 $22^{\prime} \mathrm{N}, 20^{\circ} 56^{\prime} \mathrm{E}$, 173-220 $\mathrm{m}$ a. s. 1.), in a temperate continental climate having an average annual temperature of $11.76^{\circ} \mathrm{C}$, typical of Sumadija district in Serbia and a rainfall amount of about $550 \mathrm{~mm}$.

Table 1. Precipitation sum and average monthly temperature in Kragujevac, Serbia

\begin{tabular}{ccccccccc}
\hline \multirow{2}{*}{ Months } & \multicolumn{3}{c}{ Mean monthly air temperature $\left({ }^{\circ} \mathrm{C}\right)$} & \multicolumn{5}{c}{ The amount of rainfall $(\mathrm{mm})$} \\
\cline { 2 - 9 } & $2008 / 09$ & $2009 / 10$ & $2010 / 11$ & Average & $2008 / 09$ & $2009 / 10$ & $2010 / 11$ & Aver. \\
\hline X & 13.1 & 11.7 & 10.2 & 12.5 & 31.3 & 102.6 & 86.9 & 45.4 \\
XI & 8.5 & 8.8 & 11.4 & 6.9 & 30.6 & 77.5 & 27.9 & 48.9 \\
XII & 4.4 & 2.6 & 2.4 & 1.9 & 29.7 & 194.2 & 50.1 & 56.6 \\
I & 2.3 & 0.9 & 0.9 & 0.5 & 57.7 & 57.0 & 29.1 & 58.2 \\
II & 2.0 & 3.2 & 0.5 & 2.4 & 76.9 & 150.5 & 48.5 & 46.6 \\
III & 6.8 & 7.2 & 7.2 & 7.1 & 40.3 & 43.3 & 20.4 & 32.4 \\
IV & 13.4 & 12.1 & 12.0 & 11.6 & 16.8 & 142.2 & 20.8 & 51.9 \\
V & 17.8 & 16.5 & 15.8 & 16.9 & 46.0 & 116.7 & 65.8 & 57.6 \\
VI & 20.2 & 20.2 & 20.9 & 20.0 & 137.8 & 196.7 & 32.3 & 70.4 \\
\hline
\end{tabular}




\begin{tabular}{lrrrrrrrr}
\hline Aver. & 9.83 & 9.24 & 9.03 & 8.87 & 467.1 & 1080.1 & 381.8 & 468.0 \\
\hline
\end{tabular}

Meteorological conditions recorded high variability during year. The average air temperature was higher by $0.8^{\circ} \mathrm{C}$ in $2008 / 09$, by $0.37^{\circ} \mathrm{C}$ in $2009 / 10$ and was higher by $0.16^{\circ} \mathrm{C}$ in $2010 / 11$ than the average of many years. The sum of rainfall precipitation was higher by $612.1 \mathrm{~mm}$ in 2009/10, where the sum of rainfall was lower by $0.9 \mathrm{~mm}$ in 2008/09 and was lower by $86.2 \mathrm{~mm}$ in 2010/11 than the average of many years and with a very uneven distribution of precipitation per months. During the April and May in 2009/10 it was $142.2 \mathrm{~mm}$ and $116.7 \mathrm{~mm}$ of rainfall, what was $90.3 \mathrm{~mm}$ and $59.1 \mathrm{~mm}$ more compared with the perennial average. During the June in 2009/10 it was $196.7 \mathrm{~mm}$ of rainfall, what was $126.3 \mathrm{~mm}$ more compared with the perennial average. Regard the high importance of sufficient rainfall amounts during the spring months, particularly. Namely, the total amount of precipitation is reflected on the multi annual average, but the distribution, especially at critical stages of development, is significantly disturbed in the 2009/10 year. In addition to the necessary reserve for the spring part of the vegetation, winter precipitation greatly influences the distribution of easily accessible nitrogen in the soil (Đekić et al., 2014, 2017b, 2019; Jelic et al., 2014, 2015; Milivojević et al., 2018; Popovic et. al., 2016, 2017; Terzić et al., 2018a,b).

Table 2. The analysis of variance for the tested parameters in Kragujevac, Serbia

\begin{tabular}{lccccr}
\hline Effect & df & $\begin{array}{c}\text { Mean sqr } \\
\text { Effect }\end{array}$ & $\begin{array}{c}\text { Mean sqr } \\
\text { Error }\end{array}$ & F & p-level \\
\hline \multicolumn{7}{c}{ The analysis of variance for grain yield } \\
\hline Year, (Y) & 2,117 & 23.437 & 2.708 & $8.656^{* *}$ & 0.000 \\
Fertilization, (F) & 7,112 & 38.949 & 0.813 & 47.931 & 0.000 \\
Year x Fertilization, (YxF) & 14,96 & 0.7955 & 0.344 & $2.314^{* *}$ & 0.009 \\
\hline \multicolumn{7}{c}{ The analysis of variance for 1000-grain weight } \\
\hline Year, (Y) & 2,117 & 0.715 & 3.344 & 0.214 & 0.808 \\
Fertilization, (F) & 7,112 & 7.213 & 3.056 & $2.360^{*}$ & 0.027 \\
Year x Fertilization, (YxF) & 14,96 & 16.33799 & 1.167429 & 13.99485 & 0.000 \\
\hline \multicolumn{7}{c}{ The analysis of variance for test weight } \\
\hline Year, (Y) & 2,117 & 279.970 & 4.938 & $56.698^{* *}$ & 0.000 \\
Fertilization, (F) & 7,112 & 11.567 & 9.435 & 1.226 & 0.294 \\
Year x Fertilization, (YxF) & 14,96 & 2.659 & 4.787 & 0.555 & 0.893 \\
\hline
\end{tabular}

${ }^{\text {ns }}$ non significant; ${ }^{*}$ significant at $0.05 ;{ }^{* *}$ significant at 0.01 ;

Data in Table 2 for the investigated period (2009-2011) clearly indicate that the was found highly significant effect of year on the grain yield $\left(\mathrm{F}=8.656^{* *}\right)$ and test weight $\left(\mathrm{F}=56.698^{* *}\right)$. Furthermore, 1000-grain weight was significant among the fertilization. The use of different treatments induced a significant increase in 1000-grain weight. Furthermore, test weight was highly significant among the year $\mathrm{x}$ fertilization interaction. Considerable variation in yield depending on years of research has been established by Đekić et al. (2014; 2017a), Jelic et al. (2015) and Terzić et al. (2018a). The present results confirm 
the opinion of many authors that the traits analyzed are genetically determined but are strongly modified by the nutrient status of the environment and weather conditions (Đekić et al. 2014, 2017a; Jelic et al., 2014, 2015; Milivojević et al., 2018; Popovic et. al., 2017; Stevanović et al., 2018; Ugrenović et al., 2018; Terzić et al., 2018a). Đekić et al. (2014) and Terzić et al. (2018a) find that the application of mineral fertilizers has a significant impact on the weight of 1000 grains, i.e. the grain weight is significantly higher in more intensively fertilized variants especially fertilized with nitrogen.

Table 3 presents average values for gran yield, 1000-grain weight and test weight across years and treatments during the study. The tests showed a significant grain yield and test weight. The highest values of grain yield were established in the year with moderate temperatures and high precipitation in the vegetation year 2008/09. The highest average grain yield of 4.611 t/ha of studied wheat treatments was recorded in vegetation season 2008/09 and it was significantly higher than the yield in 2009/10 (3.080 t/ha) and the yield in 2010/11 (3.827 t/ha). The 1000-grain weight of winter wheat significantly varied across treatments, from $38.25 \mathrm{~g}$ in treatment control to $40.00 \mathrm{~g}$ in treatment NPK, in a quantity of $120 \mathrm{~kg} \mathrm{~N} / \mathrm{ha}, 100$ $\mathrm{kg} / \mathrm{ha} \mathrm{P}_{2} \mathrm{O}_{5}$ and $60 \mathrm{~kg} / \mathrm{ha} \mathrm{K}_{2} \mathrm{O}$. The test weight in year 2010/11 (78.10 kg/hl) was significantly higher compared to 2008/09 and 2009/10 (76.28 kg/hl and $72.88 \mathrm{~kg} / \mathrm{hl})$. The highest grain yield had wheat application of NPK in a quantity of $120 \mathrm{~kg} / \mathrm{ha} \mathrm{N}$, $100 \mathrm{~kg} / \mathrm{ha} \mathrm{P}_{2} \mathrm{O}_{5}$ and $60 \mathrm{~kg} / \mathrm{ha} \mathrm{K}_{2} \mathrm{O}$ (5.528 t/ha).

Table 3. Mean values for grain yield, 1000-grain weight and test weight

\begin{tabular}{lcccccc}
\hline \multirow{2}{*}{ Years } & \multicolumn{2}{c}{ Grain yield (t/ha) } & \multicolumn{2}{c}{ 1000-grain weight (g) } & \multicolumn{2}{c}{ Test weight $(\mathrm{kg} / \mathrm{hl})$} \\
\cline { 2 - 7 } & $\bar{X}$ & $\mathrm{~S}$ & $\bar{X}$ & $\mathrm{~S}$ & $\bar{X}$ & $\mathrm{~S}$ \\
\hline $2008 / 09$ & $4.611^{\mathrm{a}^{\mathrm{*}}}$ & 1.673 & $39.12^{\mathrm{a}}$ & 2.259 & $76.28^{\mathrm{b}}$ & 2.531 \\
$2009 / 10$ & $3.080^{\mathrm{c}}$ & 1.435 & $39.30^{\mathrm{a}}$ & 0.851 & $72.88^{\mathrm{c}}$ & 2.312 \\
$2010 / 11$ & $3.827^{\mathrm{b}}$ & 1.807 & $39.05^{\mathrm{a}}$ & 2.051 & $78.10^{\mathrm{a}}$ & 1.750 \\
Treatments & & & & & & \\
\hline $\mathrm{C}$ & $1.292^{\mathrm{d}}$ & 0.339 & $38.25^{\mathrm{c}}$ & 2.411 & $76.91^{\mathrm{a}}$ & 3.046 \\
$\mathrm{~N}_{120}$ & $3.750^{\mathrm{b}}$ & 0.777 & $38.29^{\mathrm{c}}$ & 1.448 & $75.42^{\mathrm{ab}}$ & 2.804 \\
$\mathrm{P}_{60}$ & $2.281^{\mathrm{c}}$ & 0.865 & $39.75^{\mathrm{ab}}$ & 1.831 & $76.00^{\mathrm{ab}}$ & 3.128 \\
$\mathrm{P}_{100}$ & $2.574^{\mathrm{c}}$ & 0.858 & $39.64^{\mathrm{abc}}$ & 2.127 & $76.82^{\mathrm{ab}}$ & 3.017 \\
$\mathrm{~N}_{120} \mathrm{P}_{60}$ & $4.932^{\mathrm{a}}$ & 1.006 & $38.55^{\mathrm{bc}}$ & 1.746 & $75.01^{\mathrm{ab}}$ & 2.966 \\
$\mathrm{~N}_{120} \mathrm{P}_{100}$ & $5.101^{\mathrm{a}}$ & 0.983 & $39.39^{\mathrm{abc}}$ & 1.574 & $74.31^{\mathrm{b}}$ & 3.729 \\
$\mathrm{~N}_{120} \mathrm{P}_{60} \mathrm{~K}_{60}$ & $5.258^{\mathrm{a}}$ & 1.155 & $39.39^{\mathrm{abc}}$ & 1.165 & $76.01^{\mathrm{ab}}$ & 3.392 \\
$\mathrm{~N}_{120} \mathrm{P}_{100} \mathrm{~K}_{6}$ & $5.528^{\mathrm{a}}$ & 0.991 & $40.00^{\mathrm{a}}$ & 1.332 & $75.54^{\mathrm{ab}}$ & 2.291 \\
0 & & & & & & \\
\hline
\end{tabular}

${ }^{*}$ Means within columns followed by different lowercase letters are significantly different $(\mathrm{P}<0.05)$ according to the LSD test.

Table 4 presents average values for grain yield, 1000-grain weight and test weight across years and treatments during the three vegetation seasons. During the first years (2008/09) grain yield significantly varied across treatments, from 
$1.671 \mathrm{t} / \mathrm{ha}$ in control to $6.305 \mathrm{t} / \mathrm{ha}$ in treatment $\mathrm{N}_{120} \mathrm{P}_{100} \mathrm{~K}_{60}$. During the second years (2009/10) grain yield significantly varied across treatments, from $0.951 \mathrm{t} / \mathrm{ha}$ in control to $4.438 \mathrm{t} /$ ha in treatment $\mathrm{N}_{120} \mathrm{P}_{60} \mathrm{~K}_{60}$. During the 2010/11 years grain yield significantly varied across treatments, from 1.254 t/ha in control to 5.915 $\mathrm{t} / \mathrm{ha}$ in treatment $\mathrm{N}_{120} \mathrm{P}_{100} \mathrm{~K}_{60}$.

Table 4. Mean values of yield and quality of fertilization and vegetation seasons

\begin{tabular}{|c|c|c|c|c|c|c|}
\hline \multirow[b]{2}{*}{ 2008/09 } & \multicolumn{2}{|c|}{ Grain yield (t/ha) } & \multicolumn{2}{|c|}{ 1000-grain weight (g) } & \multicolumn{2}{|c|}{ Test weight $(\mathrm{kg} / \mathrm{hl})$} \\
\hline & $\bar{x}$ & S & $\bar{x}$ & $S$ & $\bar{x}$ & $S$ \\
\hline $\mathrm{C}$ & $1.671^{\mathrm{d}^{*}}$ & 0.190 & $40.50^{\mathrm{ab}}$ & 0.962 & $77.44^{\mathrm{a}}$ & 2.942 \\
\hline $\mathrm{N}_{120}$ & $4.410^{\mathrm{b}}$ & 0.583 & $37.03^{\text {de }}$ & 1.507 & $75.82^{\mathrm{a}}$ & 2.257 \\
\hline $\mathrm{P}_{60}$ & $3.341^{\mathrm{c}}$ & 0.463 & $41.62^{\mathrm{a}}$ & 0.691 & $75.83^{\mathrm{a}}$ & 4.029 \\
\hline $\mathrm{P}_{100}$ & $3.185^{c}$ & 0.216 & $42.00^{\mathrm{a}}$ & 0.418 & $77.91^{\mathrm{a}}$ & 1.873 \\
\hline $\mathrm{N}_{120} \mathrm{P}_{60}$ & $5.854^{\mathrm{a}}$ & 0.138 & $36.42^{\mathrm{e}}$ & 1.244 & $76.61^{\mathrm{a}}$ & 1.081 \\
\hline $\mathrm{N}_{120} \mathrm{P}_{100}$ & $5.971^{\mathrm{a}}$ & 0.280 & $37.86^{\text {cde }}$ & 1.835 & $74.93^{\mathrm{a}}$ & 2.086 \\
\hline $\mathrm{N}_{120} \mathrm{P}_{60} \mathrm{~K}_{60}$ & $6.149^{\mathrm{a}}$ & 0.355 & $38.44^{\mathrm{cd}}$ & 0.573 & $75.42^{\mathrm{a}}$ & 2.866 \\
\hline $\mathrm{N}_{120} \mathrm{P}_{100} \mathrm{~K}_{60}$ & $6.305^{\mathrm{a}}$ & 0.460 & $39.07^{\mathrm{bc}}$ & 1.718 & $76.26^{\mathrm{a}}$ & 2.522 \\
\hline \multicolumn{7}{|l|}{ 2009/10 } \\
\hline $\mathrm{C}$ & $0.951^{\mathrm{e}}$ & 0.172 & $39.04^{\mathrm{bc}}$ & 0.639 & $74.01^{\mathrm{a}}$ & 1.552 \\
\hline $\mathrm{N}_{120}$ & $2.936^{\mathrm{bc}}$ & 0.524 & $39.46^{\mathrm{ab}}$ & 0.555 & $72.37^{\mathrm{a}}$ & 1.180 \\
\hline $\mathrm{P}_{60}$ & $1.606^{\mathrm{de}}$ & 0.284 & $39.12^{\mathrm{bc}}$ & 1.250 & $73.69^{\mathrm{a}}$ & 1.539 \\
\hline $\mathrm{P}_{100}$ & $2.542^{\mathrm{cd}}$ & 1.228 & $38.22^{\mathrm{C}}$ & 0.415 & $73.57^{\mathrm{a}}$ & 2.748 \\
\hline $\mathrm{N}_{120} \mathrm{P}_{60}$ & $3.750^{\mathrm{ab}}$ & 0.641 & $39.16^{\mathrm{bc}}$ & 0.230 & $71.81^{\mathrm{a}}$ & 3.144 \\
\hline $\mathrm{N}_{120} \mathrm{P}_{100}$ & $4.054^{\mathrm{a}}$ & 0.602 & $39.96^{\mathrm{ab}}$ & 0.297 & $70.88^{\mathrm{a}}$ & 3.007 \\
\hline $\mathrm{N}_{120} \mathrm{P}_{60} \mathrm{~K}_{60}$ & $4.438^{\mathrm{a}}$ & 1.429 & $39.22^{\mathrm{b}}$ & 0.965 & $73.33^{\mathrm{a}}$ & 2.763 \\
\hline $\mathrm{N}_{120} \mathrm{P}_{100} \mathrm{~K}_{60}$ & $4.363^{\mathrm{a}}$ & 0.693 & $40.26^{\mathrm{a}}$ & 0.451 & $73.41^{\mathrm{a}}$ & 1.220 \\
\hline \multicolumn{7}{|l|}{ 2010/11 } \\
\hline $\mathrm{C}$ & $1.254^{\mathrm{e}}$ & 0.103 & $35.21^{d}$ & 0.616 & $79.28^{\mathrm{a}}$ & 1.879 \\
\hline $\mathrm{N}_{120}$ & $3.902^{\mathrm{C}}$ & 0.312 & $38.38^{\mathrm{C}}$ & 1.029 & $78.07^{\mathrm{abc}}$ & 0.656 \\
\hline $\mathrm{P}_{60}$ & $1.896^{\mathrm{de}}$ & 0.409 & $38.51^{\mathrm{c}}$ & 1.702 & $78.48^{\mathrm{abc}}$ & 1.118 \\
\hline $\mathrm{P}_{100}$ & $1.994^{\mathrm{d}}$ & 0.363 & $38.71^{\mathrm{bc}}$ & 2.216 & $78.98^{\mathrm{ab}}$ & 0.521 \\
\hline $\mathrm{N}_{120} \mathrm{P}_{60}$ & $5.192^{\mathrm{b}}$ & 0.469 & $40.02^{\mathrm{abc}}$ & 0.468 & $76.61^{\mathrm{c}}$ & 0.727 \\
\hline $\mathrm{N}_{120} \mathrm{P}_{100}$ & $5.277^{\mathrm{ab}}$ & 0.767 & $40.35^{\mathrm{ab}}$ & 0.858 & $77.12^{\mathrm{abc}}$ & 3.195 \\
\hline $\mathrm{N}_{120} \mathrm{P}_{60} \mathrm{~K}_{60}$ & $5.187^{\mathrm{b}}$ & 0.816 & $40.52^{\mathrm{a}}$ & 0.847 & $79.29^{\mathrm{a}}$ & 1.249 \\
\hline $\mathrm{N}_{120} \mathrm{P}_{100} \mathrm{~K}_{60}$ & $5.915^{\mathrm{a}}$ & 0.332 & $40.67^{\mathrm{a}}$ & 1.154 & $76.94^{\mathrm{bc}}$ & 1.323 \\
\hline
\end{tabular}

*Means within columns followed by different lowercase letters are significantly different $(\mathrm{P}<0.05)$ according to the LSD test.

The 1000-grain weight of winter wheat significantly varied across years and treatments. During the 2008/09 years 1000-grain weight significantly varied across treatments from $36.42 \mathrm{~g}$ in treatment $\mathrm{N}_{120} \mathrm{P}_{60}$ to $40.50 \mathrm{~g}$ in control. During the 2009/10 years 1000-grain weight significantly varied across treatments from $38.22 \mathrm{~g}$ in treatment $\mathrm{P}_{60}$ to $40.26 \mathrm{~g}$ in $\mathrm{N}_{120} \mathrm{P}_{100} \mathrm{~K}_{60}$. During the 2010/11 years 
1000-grain weight significantly varied across treatments from $35.21 \mathrm{~g}$ in control to $40.67 \mathrm{~g}$ in $\mathrm{N}_{120} \mathrm{P}_{100} \mathrm{~K}_{60}$.

The test weight of winter wheat significantly varied across years and treatments. Averaged across 2008/09 years, significantly higher values for test weight were found in the treatment $\mathrm{P}_{60}(77.91 \mathrm{~kg} / \mathrm{hl})$, in $2009 / 10$ in the control $(74.01$ $\mathrm{kg} / \mathrm{hl})$ and in 2010/11 in the control and treatment $\mathrm{N}_{120} \mathrm{P}_{60} \mathrm{~K}_{60}(79.28 \mathrm{~kg} / \mathrm{hl}$ and 79.29 $\mathrm{kg} / \mathrm{hl})$.

Table 5. Correlations between the traits analyzed by three vegetation seasons

\begin{tabular}{|c|c|c|c|}
\hline Traits & Grain yield & 1000-grain weight & Test weight \\
\hline \multicolumn{4}{|c|}{ Correlations between the traits analyzed in $2008 / 2009$} \\
\hline Grain yield $\left(\mathrm{t} \mathrm{ha}^{-1}\right)$ & 1.00 & $-0.562^{* *}$ & $-0.242^{\mathrm{ns}}$ \\
\hline 1000-grain weight (g) & & 1.00 & $0.113^{\mathrm{ns}}$ \\
\hline Test weight $\left(\mathrm{kg} \mathrm{hl}^{-1}\right)$ & & & 1.00 \\
\hline \multicolumn{4}{|c|}{ Correlations between the traits analyzed in 2009/2010 } \\
\hline Grain yield $\left(\mathrm{t} \mathrm{ha}^{-1}\right)$ & 1.00 & $0.450^{*}$ & $-0.050^{\mathrm{ns}}$ \\
\hline 1000-grain weight (g) & & 1.00 & $0.045^{\mathrm{ns}}$ \\
\hline Test weight $\left(\mathrm{kg} \mathrm{hl}^{-1}\right)$ & & & 1.00 \\
\hline \multicolumn{4}{|c|}{ Correlations between the traits analyzed in 2010/2011 } \\
\hline Grain yield $\left(\mathrm{t} \mathrm{ha}^{-1}\right)$ & 1.00 & $0.711^{* *}$ & $-0.443^{*}$ \\
\hline 1000-grain weight (g) & & 1.00 & $-0.284^{\mathrm{ns}}$ \\
\hline Test weight $\left(\mathrm{kg} \mathrm{hl}^{-1}\right)$ & & & 1.00 \\
\hline
\end{tabular}

Table 5 presents the correlation coefficients between the years and examined traits. Test weight in 2008/09 was positively correlated with 1000grain weight $(\mathrm{r}=0.113)$ and negatively but dependent significantly correlated with grain yield and 1000-grain weight $\left(r=-0.562^{* *}\right)$. Wheat yield in 2009/10 was positively and significantly correlated with 1000 -grain weight $\left(r=0.450^{*}\right)$. The correlative dependence of the grain yield in the 2010/11 vegetation season in was positively and highly significant correlation with the 1000-grain weight $\left(\mathrm{r}=0.711^{* *}\right)$. Grain yield depends directly on the number of grains per spike and the 1000-grain weight (Hristov et al., 2011; Đekić et al., 2014, 2017a; Terzić et al., 2018a).

Table 6 presents the correlation coefficients between the treatments and examined traits. The correlative dependence of the grain yield in the treatment $\mathrm{P}_{1}$ in was positively and highly significant correlation with the 1000-grain weight $\left(\mathrm{r}=0.806^{* *}\right)$. Positive correlations were observed between grain yield and test weight in all treatments. Positively and medium significantly correlations were also found between grain yield and test weight in the $\mathrm{N}\left(\mathrm{r}=0.533^{*}\right)$ and positively but strong significantly correlated were also found in the $\mathrm{NP}_{1}\left(\mathrm{r}=0.846^{* *}\right)$ treatments. Negative correlation between 1000-grain weight and test weight has been established (Đekić et al., 2017c; Terzić et al., 2018a). 
Table 6. Correlation coefficients for the traits analyzed across treatments

\begin{tabular}{|c|c|c|c|}
\hline & Grain yield & 1000-grain weight & Test weight \\
\hline \multicolumn{4}{|c|}{ Correlations between the traits analyzed in the unfertilized control } \\
\hline Grain yield $\left(\mathrm{t} \mathrm{ha}^{-1}\right)$ & 1.00 & $0.343^{\mathrm{ns}}$ & $0.450^{\mathrm{ns}}$ \\
\hline 1000-grain weight (g) & & 1.00 & $-0.344^{\mathrm{ns}}$ \\
\hline Test weight $\left(\mathrm{kg} \mathrm{hl}^{-1}\right)$ & & & 1.00 \\
\hline \multicolumn{4}{|c|}{ Correlations between the traits analyzed in the $\mathrm{N}$} \\
\hline Grain yield $\left(\mathrm{t} \mathrm{ha}^{-1}\right)$ & 1.00 & $-0.463^{\mathrm{ns}}$ & $0.533^{*}$ \\
\hline 1000-grain weight (g) & & 1.00 & $-0.409^{\mathrm{ns}}$ \\
\hline Test weight $\left(\mathrm{kg} \mathrm{hl}^{-1}\right)$ & & & 1.00 \\
\hline \multicolumn{4}{|c|}{ Correlations between the traits analyzed in the $\mathrm{P}_{1}$} \\
\hline Grain yield $\left(\mathrm{t} \mathrm{ha}^{-1}\right)$ & 1.00 & $0.806^{* *}$ & $0.169^{\mathrm{ns}}$ \\
\hline 1000-grain weight (g) & & 1.00 & $-0.158^{\mathrm{ns}}$ \\
\hline Test weight $\left(\mathrm{kg} \mathrm{hl}^{-1}\right)$ & & & 1.00 \\
\hline \multicolumn{4}{|c|}{ Correlations between the traits analyzed in the $\mathrm{P}_{2}$} \\
\hline Grain yield $\left(\mathrm{t} \mathrm{ha}^{-1}\right)$ & 1.00 & $0.501^{\mathrm{ns}}$ & $0.094^{\mathrm{ns}}$ \\
\hline 1000-grain weight (g) & & 1.00 & $0.300^{\mathrm{ns}}$ \\
\hline Test weight $\left(\mathrm{kg} \mathrm{hl}^{-1}\right)$ & & & 1.00 \\
\hline \multicolumn{4}{|c|}{ Correlations between the traits analyzed in the $\mathrm{NP}_{1}$} \\
\hline Grain yield $\left(\mathrm{t} \mathrm{ha}^{-1}\right)$ & 1.00 & $-0.481^{\mathrm{ns}}$ & $0.846^{* *}$ \\
\hline 1000-grain weight (g) & & 1.00 & $-0.131^{\mathrm{ns}}$ \\
\hline Test weight $\left(\mathrm{kg} \mathrm{h}^{-1}\right)$ & & & 1.00 \\
\hline \multicolumn{4}{|c|}{ Correlations between the traits analyzed in the $\mathrm{NP}_{2}$} \\
\hline Grain yield $\left(\mathrm{t} \mathrm{ha}^{-1}\right)$ & 1.00 & $-0.458^{\mathrm{ns}}$ & $0.364^{\mathrm{ns}}$ \\
\hline 1000-grain weight (g) & & 1.00 & $-0.111^{\mathrm{ns}}$ \\
\hline Test weight $\left(\mathrm{kg} \mathrm{hl}^{-1}\right)$ & & & 1.00 \\
\hline \multicolumn{4}{|c|}{ Correlations between the traits analyzed in the $\mathrm{NP}_{1} \mathrm{~K}$} \\
\hline Grain yield $\left(\right.$ tha $^{-1}$ ) & 1.00 & $-0.072^{\mathrm{ns}}$ & $0.167^{\mathrm{ns}}$ \\
\hline 1000-grain weight (g) & & 1.00 & $0.675^{*}$ \\
\hline Test weight $\left(\mathrm{kg} \mathrm{hl}^{-1}\right)$ & & & 1.00 \\
\hline \multicolumn{4}{|c|}{ Correlations between the traits analyzed in the $\mathrm{NP}_{2} \mathrm{~K}$} \\
\hline Grain yield $\left(\mathrm{t} \mathrm{ha}^{-1}\right)$ & 1.00 & $-0.094^{\mathrm{ns}}$ & $0.461^{\mathrm{ns}}$ \\
\hline 1000-grain weight (g) & & 1.00 & $-0.288^{\mathrm{ns}}$ \\
\hline Test weight $\left(\mathrm{kg} \mathrm{hl}^{-1}\right)$ & & & 1.00 \\
\hline
\end{tabular}

${ }^{\text {ns }}$ non significant; ${ }^{*}$ significant at $0.05 ;{ }^{* *}$ significant at 0.01 ;

\section{CONCLUSIONS}

Effects of mineral nutrition efficiency of wheat have been studied at the stationary field trial of the Institute of Small Grains Research Centre in Kragujevac (Serbia) for three years (2008/09, 2009/10 and 2010/11). Nitrogen had a most significant impact on the yield of wheat. The average grain yield of all treatments in the 2008/09 growing season was significant greater than in the following years. The highest average yields were gained by $\mathrm{N}_{120} \mathrm{P}_{100} \mathrm{~K}_{60}$ treatment (5.528 t/ha), $\mathrm{N}_{120} \mathrm{P}_{60} \mathrm{~K}_{60}$ treatment (5.258 t/ha) and $\mathrm{N}_{120} \mathrm{P}_{100}$ treatment 
(5.101 t/ha) in three-year period. The analysis of variance indicated highly significant effects of year on the grain yield and test weight. Effects of fertilization on the 1000-grain weight were statistically significant. Interaction between the analysed factors (year $\mathrm{x}$ fertilization) shows a highly significant effect on 1000-grain weight in wheat. The average grain yield was significantly higher in 2008/09, while in 2010/11 of test weight was significantly higher.

In 2008/09 a negatively and medium-dependent significant correlation was found between grain yield and 1000-grain weight $\left(-0.562^{* *}\right)$ as well as a significant positive correlation in $2009 / 10\left(0.450^{*}\right)$, while these positive and strong correlations in 2010/11 were highly significant $\left(0.711^{* *}\right)$.

\section{ACKNOWLEDGEMENTS}

Investigations necessary for this paper are part of the project TR 31054 financed by the Ministry of Education, Science and Technology Development of Republic of Serbia and bilateral projects (Montenegro and Serbia; 2019-2020): "Alternative cereals and oil crops as a source of healthcare food and an important raw material for the production of biofuel" and FAO project: "Redesigning the exploitation of small grains genetic resources towards increased sustainability of grain-value chain and improved farmers' livelihoods in Serbia and Bulgaria GRAINEFIT; 2019-2021“.

\section{REFERENCES}

Dodig, D., Zorić, M., Knežević, D., King, S., Šurlan-Momirović, G. (2008): Genotype x environment interaction for wheat yield in different drought stress conditions and agronomic traits suitable for selection. Australian Journal of Agricultural Research, 59: 536-545.

Đekić, V., Milovanović, M., Popović, V., Milivojević, J., Staletić, M., Jelić, M., Perišić, V. (2014): Effects of fertilization on yield and grain quality in winter triticale. Romanian Agricultural Research, 31: 175-183.

Đekić, V., Milovanović, M., Milivojević, J., Staletić, M., Popović, V., Simić, D., Mitrović, M. (2015): Impact of year and grain quality of winter wheat. Proceedings of research papers PKB Agroekonomik, 21(1-2): 79-86.

Đekić, V., Jelić, M., Milivojević, J., Popović, V., Branković, S., Staletić, M., Terzić, D. (2017a): Winter wheat yield and yield components depending on the level of nitrogen, phosphorus and potassium fertilization. Proceedings, VIII International Scientific Agriculture Symposium "Agrosym 2017", Jahorina, 650-657.

Đekić, V., Popović, V., Branković, S., Terzić, D., Đurić, N (2017b): Yield components and grain yield of winter barley. Agriculture and Forestry, 63(1): 179-185, DOI: 10.17707/AgricultForest.63.1.21.

Đekić, V., Milivojević, J., Jelić, M., Popović, V., Branković, S., Biberdžić, M., Terzić, D. (2017c): Effects of fertilization on production traits of Takovčanka cultivar of winter wheat. Proceedings, 2nd International and 14th National Congress of Soil Science Society of Serbia "Solutions and Projections for Sustainable Soil Management”. NSoil 2017, 25-28th September 2017, Novi Sad, Serbia, 49-54.

Đekić, V., Popović, V., Terzić, D., Đurić, N., Perišić, V., Perišić, V., Luković, K. (2019): The impact of climate change on the grain yeald of wheat. Proceedings of research papers PKB Agroekonomik, Belgarde, 25(1-2): 9-18.

Djuric, N., Prodanovic, S., Brankovic, G., Djekic, V., Cvijanovic, G., Zilic, S., Dragicevic, V., Zecevic, V., Dozet, G., (2018): Correlation-Regression Analysis of Morphological-Production Traits of Wheat Varieties. Romanian Biotechnological Letters, 23(2): 13457-13465. 
Hristov, N., Mladenov, N., Kondić-Špika, A. (2011): Effect of environmental and genetic factors on the correlation and stability of grain yield components in wheat. Genetika, 43(1): 141-152.

Jelić, M., Milivojević, J., Đekić, V., Paunović, A., Tmušić, N. (2014): Impact of liming and fertilization on grain yield and utilization of nitrogen and phosphorus in wheat plant grown on soil type pseudogley. Proceedings of research papers PKB Agroekonomik, Belgarde, 20(1-4): 49-56.

Jelic, M., Milivojevic, J., Nikolic, O., Djekic, V., Stamenkovic, S. (2015): Effect of longterm fertilization and soil amendments on yield, grain quality and nutrition optimization in winter wheat on an acidic pseudogley. Romanian Agricultural Research, 32: 165-174.

Jelić, M., Milivojević, J., Paunović, A., Madić, M., Đekić, V. (2016): Adaptation of winter wheat genotypes to low ph and high mobile al content in the soil. Proceedings, VII International Scientific Sympozium "Agrosym Jahorina 2016", AGROSYM, 06-09. October, Jahorina, 762-767.

Jordanovska, S., Jovović, Z., Dolijanović, Ž., Dragičević, V., Branković, G., Đekić, V. (2018): Nutritional properties of macedonian landraces of small grain cereals as a source of new genetic variability. Genetics, 50(3): 863-883. https://doi.org/10.2298/GENSR1803863J

Milivojević, J., Bošković-Rakočević, Lj., Đekić, V., Luković, K., Simić, Z. (2018): Cultivar-specific accumulation of iron, manganese, zinc and copper in winter wheat grain (Triticum aestivum L.). Journal of Central European Agriculture, 19(2): 423-436. https://doi.org/10.5513/JCEA01/19.2.2051

Popović, V., Vidić, M., Ikanović, J., Filipović, V., Đekić, V., Tabaković, M., Veselić, J. (2016): Soybean oil yield as affected by the growing locality in agro-climatic divergent years. Agriculture and Forestry, 62 (1): 217-225. DOI: 10.17707/AgricultForest.62.1.25.

Popović, V., Tatić, M., Spalević, V., Rajičić, V., Filipović, V., Šarčević-Todosijević, LJ., Stevanović, P. (2017): Effect of nitrogen fertilization on soybean plant height in arid year. Proceedings, 2nd International and 14th National Congress of Soil Science Society of Serbia "Solutions and Projections for Sustainable Soil Management”. 25-28th September 2017, Novi Sad, Serbia, 65-73.

Popović, V., Kolarić, lj., Živanović, LJ., Ikanović, J., Rajičić, V., Dozet, G., Stevanović, P. (2018): Influence of row spacing on nar-net photosynthesis productivity of Glycine max (L.) Merrill. Agriculture \& Forestry, 64 (1): 159-169. DOI: 10.17707/AgricultForest.64.1.18.

Terzic, D., Đekić, V., Jevtic, S., Popovic, V., Jevtic, A., Mijajlovic, J., Jevtic, A. (2018a): Effect of long term fertilization on grain yield and yield components in winter triticale. The Journal of Animal and Plant Sciences, 28(3): 830-836.

Terzić, D., Đekić, V., Milivojević, J., Branković, S., Perišić, V., Perišić, V., Đokić, D. (2018b): Yield components and yield of winter wheat in different years of research. Biologica Nyssana, 9(2): 119-131. DOI: 10.5281/zenodo.2538604

SAS/STAT (2000): User's Guide, Version 9.1.3. SAS Institute Inc.

Stevanović, P., Popović, V., Jovović, Z., Ugrenović, V., Rajičić, V., Popović, S., Filipović, V. (2018): Quality of wheat seed in respect of fragment and feeding locality. Journal of Institute of PKB Agroekonomik, Belgrade, 24 (1-2): 65-74.

Ugrenović, V., Bodroža Solarov, M., Pezo, L., Đisalov, J., Popović, V., Marić, B., Filipović ,V. (2018): Analysis of spelt variability (Triticum spelta L.) grown in different conditions of Serbia by organic conditions. Genetika, 50 (2): 635-646. 